
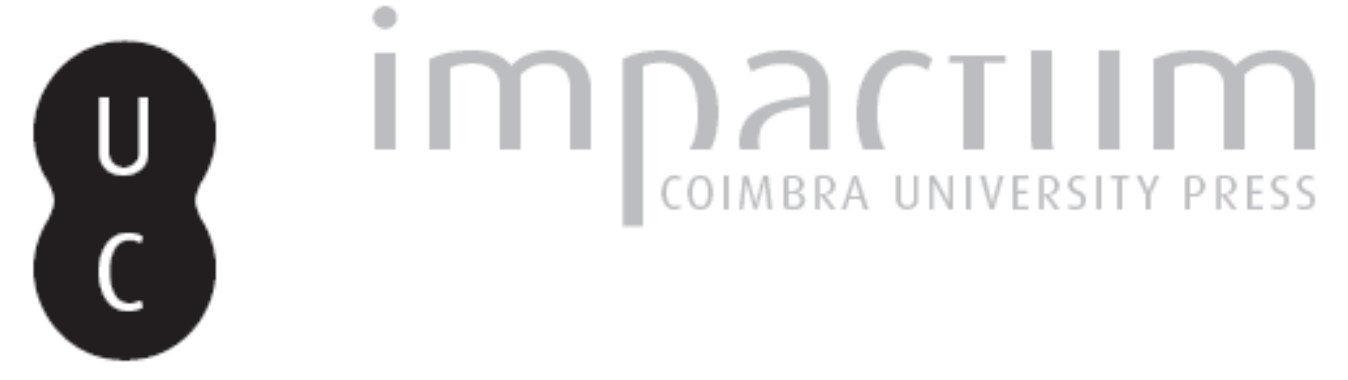

\title{
Cerâmica romana de paredes finas no Museu Municipal de Elvas
}

Autor(es): $\quad$ Sepúlveda, Eurico; Carvalho, António

Publicado por: Imprensa da Universidade de Coimbra

URL persistente:

URl:http://hdl.handle.net/10316.2/45411

DOI:

DOI:https://dx.doi.org/10.14195/1647-8657_37_9

Accessed : $\quad$ 26-Apr-2023 09:59:55

A navegação consulta e descarregamento dos títulos inseridos nas Bibliotecas Digitais UC Digitalis, UC Pombalina e UC Impactum, pressupõem a aceitação plena e sem reservas dos Termos e Condições de Uso destas Bibliotecas Digitais, disponíveis em https://digitalis.uc.pt/pt-pt/termos.

Conforme exposto nos referidos Termos e Condições de Uso, o descarregamento de títulos de acesso restrito requer uma licença válida de autorização devendo o utilizador aceder ao(s) documento(s) a partir de um endereço de IP da instituição detentora da supramencionada licença.

Ao utilizador é apenas permitido o descarregamento para uso pessoal, pelo que o emprego do(s) título(s) descarregado(s) para outro fim, designadamente comercial, carece de autorização do respetivo autor ou editor da obra.

Na medida em que todas as obras da UC Digitalis se encontram protegidas pelo Código do Direito de Autor e Direitos Conexos e demais legislação aplicável, toda a cópia, parcial ou total, deste documento, nos casos em que é legalmente admitida, deverá conter ou fazer-se acompanhar por este aviso.

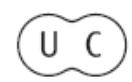


UNIVERSIDADE DE COIMBRA

FACULDADE DE LETRAS

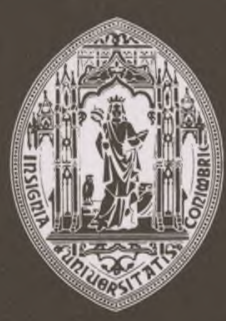

\section{CONIMBRIGA}

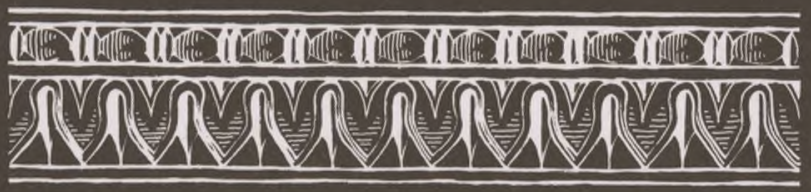

VOLUME XXXVII - 1998 


\section{EURICO SEPÚLVEDA}

Licenciado em Economia

António Carvalho

Biblioteca Condes de Castro Guimarães da Câmara Municipal de Cascais

e Centro de Arqueologia da Universidade de Lisboa

CERÂMICA ROMANA DE PAREDES FINAS

NO MUSEU MUNICIPAL DE ELVAS

"Conimbriga" XXXV (1996) p. 233-265

Resumo: os autores estudam um pequeno corpus de materiais constituído pela totalidade de recipientes de cerâmica de paredes finas -7 peças depositados no Museu Municipal de Eivas e provenientes de três sítios arqueológicos deste concelho: necrópole da Herdade do Padrão, necrópole da Horta das Pinas e necrópole (?) da Herdade de Fontal va.

$\mathrm{O}$ artigo enumera as limitações que o estudo deste corpus coloca, descreve sucintamente os sítios arqueológicos em questão, discute problemas de tipologia, paralelos, origens e cronologias, bem como apresenta o catálogo dos materiais. Relaciona ainda as formas presentes com peças semelhantes exumadas nas escavações, actualmente em curso, na mila romana da Quinta das Longas, também no concelho de Eivas.

Résumé: Les auteurs étudient un petit corpus qui constitue la totalité des vases de céramique à parois fines -7 exemplaires — qui appartient au Museu Municipal de Elvas, provenant de trois sites archéologiques dans la région d'Elvas: nécropole de 1' Herdade do Padrão, nécropole de 1'Horta das Pinas et nécropole (?) de 1'Herdade de Fontalva.

L'article énumère les limitations que l'étude de ce corpus suscite, il décrit sommairement les sites archéologiques, il fait la discussion des problèmes de typologie, des paralèlles, des origines, des cronologies, et présente le catalogue du mobilier céramique. On met aussi en rapport formes du corpus avec des exemplaires similaires exhumés pendant les fouilles, actuellement en cours, de la uilla romaine de Quinta das Longas, à Elvas. 
(Página deixada propositadamente em branco) 


\title{
CERÂMICA ROMANA DE PAREDES FINAS NO MUSEU MUNICIPAL DE ELVAS
}

\author{
"A r ouest de Mérida, ce sont les nécropoles de la région d'Elvas qui ont fourni \\ un grand nombre de vases à parois fines se rattachant bien évidemment à la produc- \\ tion éméritaine, y compris une forme qui n'a pas encore été trouvée dans le centre \\ producteur $\left(n .{ }^{\circ} 595\right)$. " (MAYETXLVI) \\ Françoise Mayet, 1975, p. 145.
}

\section{Introdução}

O presente artigo estuda um pequeno corpus constituído pela totalidade das cerâmicas de paredes finas romanas, pertencentes às colecções do Museu Municipal “António Thomaz Pires”, de Eivas.

Estas peças, num total de sete, estão dispersas por três espaços do Museu. Uma das peças está exposta numa vitrina com materiais de época romana, localizada na ala sul do corredor do piso superior do edifício; quatro estão contentorizadas nas reservas do Museu; e outras duas ocupam uma vitrine instalada numa pequena sala, onde se encontra reunida a quase totalidade do espólio romano depositado nesta instituição. Por se tratar, também, do gabinete de trabalho do técnico de conservação e restauro, a sala nem sempre está incluída no circuito normal das visitas, o que contribui para acentuar o desconhecimento por parte de todos os interessados, e também dos especialistas, relativamente à existência destas peças. Esta situação é naturalmente agravada pelo facto de se encontrarem inéditas, pois nunca foram objecto de estudo enquanto peças de cerâmica fina. Apenas estão referenciadas de forma pouco precisa nos artigos de 
Abel Viana e António Dias Deusí1), que inventariam o espólio recolhido nas centenas de sepulturas das várias necrópoles que, separadamente ou em conjunto, escavaram no concelho de Eivas.

Quanto à terminologia, pode imputar-se a estes autores responsabilidades pela não utilização da designação convencional - cerâmica de paredes finas —, usando em seu lugar a fórmula "cerâmica de pasta fina de barro branco com barbotina"( $\left.{ }^{2}\right)$, e outras variantes, para classificar os materiais em questão. Pois convém notar que Nino Lamboglia $\left(^{3}\right)$ tinha publicado, em Itália, na mesma época, um primeiro estudo fundamental — antecedido por alguns artigos - onde, pela primeira vez, enquadra cronologicamente as "ceramiche a pareti sottili" no conjunto das cerâmicas romanas. Alguns destes contributos são já do conhecimento destes autores, pois aparecem citados nos artigos sobre as necrópoles elvenses $\left(^{4}\right)$. Mas, em Portugal, só a partir de meados da década

O De entre a extensa lista bibliográfica destes autores sobre as escavações e prospecções que realizaram, individualmente ou em conjunto com outros estudiosos, no concelho de Eivas, nas décadas de 40 e 50, destacamos aqueles que constituem os relatos mais pormenorizados das intervenções arqueológicas efectuadas nas necrópoles: viana, Abel (1950) - Contribuição para a arqueologia dos arredores de Eivas. Trabalhos de Antropologia e Etnologia. Porto: Instituto de Antropologia-Faculdade de Ciências, 12(34), p. 289-322; viana, Abel e Deus, António Dias de (1950) - Necrópolis céltico-romanas del concejo de Eivas (Portugal). Archivo Español de Arqueologia. Madrid: Consejo Superior de Investigaciones Cientificas-Instituto Diego Velazquez. 23 (80), p. 229-254; Idem (1953) - Exploração de algumas necrópoles céltico-romanas do concelho de Elvas. In: XIII Congresso Luso-Espanhol para o Progresso das Ciências - Lisboa - 1950 - 7 a Secção - Ciências Históricas e Filosóficas. Lisboa: Associação Portuguesa para o Progresso das Ciências, 8, p. 67-74; Idem (1955a) - Nuevas necropolis celto-romanas de la region de Eivas (Portugal). Archivo Español de Arqueologia. Madrid: Consejo Superior de Investigaciones Cientificas-Instituto Español de Arqueologia y Prehistoria "Rodrigo Caro". 28(91) p. 33-68; Idem (1955b) - Necropolis de la Torre das Arcas. Archivo Español de Arqueologia. Madrid: Consejo Superior de Investigaciones Cientificas-Instituto Español de Arqueologia y Prehistoria "Rodrigo Caro". 28(92) p. 244-263; Idem (1956) - Campos de urnas do concelho de Elvas. O Instituto: Revista Cientifica e Literária. Coimbra: Instituto de Coimbra, 118, p. 133-193.

(2) Cf., entre outros, por exemplo, viana, A. e Deus, A. D. de (1955a) - Op. cit., p. 44.

(3) Lamboglia, Nino (1950) - Gli scavi di Albintimilium e la cronologia della ceramica romana, Parte Prima, Campagne di Scavo 1938-1940. Bordighera: Istituto Intemazional di Studi Liguri.

(4) Lamboglia, Nino (1949) - La estratigrafía de Albintimilium y la cronologia de la ceràmica romana. Ampurias. Barcelona: Diputación Provincial de Barcelona-Ins- 
de 50(5) é que os nossos investigadores começam a utilizar regularmente a terminologia estabelecida pelo autor italiano.

A opção pela publicação destas peças surgiu na sequência de um pedido endereçado à Câmara Municipal de Eivas, para consulta do inventário e estudo de todos os materiais arqueológicos depositados no Museu, provenientes de sítios com ocupação romana já identificada. Assim, ao proceder ao levantamento dos materiais romanos, verificámos que as cerâmicas de paredes finas, entre muitos outros tipos de espólio, nunca tinham sido objecto de qualquer análise detalhada, apesar de constituírem artefactos de assinalável importância pela informação cronológica e distributiva que transmitem, merecendo, portanto, um estudo exaustivo e actualizado, face ao estado actual dos nossos conhecimentos. Dessa elementar constatação surgiu a intenção de as publicar.

$\mathrm{O}$ interesse pelo estudo dos materiais da época romana depositados no Museu Municipal de Eivas entronca no facto de um dos signatários deste artigo (A. C.) dirigir, desde 1990, um projecto de investigação arqueológica na villa romana da Quinta das Longas (S. Vicente e Ventosa, Eivas), que tem como um dos objectivos paralelos relacionar os resultados já obtidos nos trabalhos realizados com a informação artefactual proveniente de outros sítios arqueológicos romanos localizados na área envolvente desta uilla. Naturalmente que, e face à exiguidade de estudos publicados sobre as colecções depositadas no Museu e os respectivos contextos, a análise destes materiais revela-se imprescindível para obter algumas informações válidas - embora muito parcas quando comparadas com os nossos desejos -, que contribuam para preencher o quadro de conhecimentos sobre o período romano, que, para a região de Eivas, prima ainda por mostrar grandes vazios, em contraste absoluto com o significativo número de sítios já identificados.

No verão de 1995, paralelamente aos trabalhos da 5. ${ }^{\text {a }}$ campanha de escavações na villa romana da Quinta das Longas, foram desenhadas $\left({ }^{6}\right)$ e

-tituto Diego Velázquez. 11, p. 47-61 ; citado, por exemplo, em VianA, A. e Deus, A. D. de (1956) - Op. cit., p. 29.

(5) O primeiro autor português que utiliza a denominação - cerâmica de paredes finas - parece ter sido Fernando Nunes Ribeiro. Cf. Riвerro, Fernando Nunes (1956) - Breve informação sobre cerâmica romana das Represas. Beja: Ed. do autor.

${ }^{6}$ ) Os desenhos das peças do catálogo foram realizados por alunos da Licenciatura em História (Variante de Arqueologia) da Faculdade de Letras da Universidade de Lisboa,

Conimbriga, 37 (1998), 233-265 
descritas $\left({ }^{7}\right)$ as cerâmicas de paredes finas e as ânforas, devendo estas últimas ser objecto de um futuro artigo. Pretendemos que o estudo de materiais do Museu prossiga nos próximos anos.

$\mathrm{O}$ estudo destas peças revela-se essencial para uma mais fina caracterização cronológica dos arqueossítios de onde são provenientes pois, apesar destes terem sido objecto de escavações arqueológicas, e terem inclusive merecido vários artigos sobre os trabalhos ali realizados e os contextos estratigráficos então identificados, nunca os materiais exumados mereceram um estudo técnico e tipologico detalhado, não permitindo assim avaliar com rigor qual a sua efectiva importância. Além dos escavadores, outros arqueólogos têm dedicado, em diversas ocasiões, alguma atenção a estes locais. Porém, devido à ausência de tais estudos tipológicos e de monografias exaustivas, limitam-se a acreditar tratarem-se de sítios - necrópoles e, em alguns casos, com habitat associado -, muito extensos em área ocupada, longamente utilizados (e com várias fases) e de grande riqueza informativa, no entanto, insuficientemente trabalhada e explorada $\left({ }^{8}\right)$.

\section{Limitações do presente estudo}

Embora o presente trabalho tenha por objecto de estudo um corpus constituído por apenas sete peças, tal não significa que as limitações encontradas sejam também escassas. Pelo contrário, a análise detalhada destas peças, dos respectivos contextos, das cronologias propostas, das técnicas de restauro e conservação utilizadas e de muitas outras questões paralelas, constituem entraves ou problemas de difícil resolução.

A primeira incógnita não resolvida tem a ver com o depósito destes materiais no Museu Municipal de Eivas. Desconhecemos, em absoluto, a razão, ou razões, que determinaram que deste conjunto de sete peças de cerâmica de paredes finas, seis, provenientes das necrópoles escava-

tendo posteriormente sido corrigidos e tintados por um dos signatários do artigo (E. S.). Os autores dos desenhos são: peça n..$^{\circ} 1$ - Ana Filipa Pereira; peças n. ${ }^{\circ} 2$ e 7 - Ana Sofia Gomes; peças n..$^{\circ} 3$ e 5 - Paulo Jorge Neves; peça n. ${ }^{\circ} 4$ - Carla Sofia Fernandes; e peça.$^{\circ} 6$ - Maria Manuela Pereira.

(7) A descrição das peças é também da responsabilidade de E. S.

$\left({ }^{8}\right)$ No grupo dos principais autores destacam-se os que nos últimos anos elaboraram sínteses sobre o Portugal romano, e que nesse âmbito trataram o tema, designadamente, Jorge de Alarcão (em diversas ocasiões), Rui Centeno e Carlos Fabião.

Conimbriga, 37 (1998), 233-265 
das por Abel Viana e António Dias de Deus, tenham ficado em Eivas - acompanhadas por outros materiais é certo -, quando o grosso do espólio foi depositado no Museu do Paço Ducal de Vila Viçosa. No Museu de Eivas não há qualquer registo que nos esclareça, embora uma pesquisa na documentação do Museu ou na correspondência pessoal dos escavadores e nos seus cadernos de campo( $\left.{ }^{9}\right)$, nos pudesse dar algumas pistas interessantes. Não excluímos a possibilidade, que julgamos até bastante provável, de os materiais terem sido propositadamente deixados em Eivas para serem mostrados aos visitantes do Museu como mero testemunho das necrópoles elvenses ou para eventual comparação futura com outros materiais a exumar. O que parece certo é que a sua selecção foi aleatória.

Quanto à nossa peça n. ${ }^{\circ} 5$, proveniente da Herdade de Fontalva, coloca-se necessariamente outro problema, aparentemente de fácil resolução. Por que razão está ela depositada no Museu Municipal de Eivas, quando o espólio que foi recolhido nesta Herdade pelo respectivo proprietário Rui de Andrade, e posteriormente publicado por três arqueólogos incluindo Abel Viana, deu entrada no Museu dos Serviços Geológicos, em Lisboa? A resposta pode estar no facto do autor e o momento das recolhas serem efectivamente outros, e não o proprietário $\left({ }^{10}\right)$, durante a década de 40 .

É habitualmente considerado pelos investigadores que os materiais arqueológicos exumados das necrópoles elvenses escavadas e publicadas por Abel Viana e António Dias de Deus estão depositados no Paço Ducal de Vila Viçosa, e, no entanto, deparamos com este pequeno núcleo, integrado por vários tipos de peças, no Museu Municipal de Eivas. Deve ter sido esta ideia feita que afastou F. Mayet, na primeira metade da década de 70, do estudo dos sete exemplares que agora apresentamos. F. Mayet não os deverá ter identificado, até porque o conhecimento do

(9) Segundo Abel Viana, António Dias de Deus "não tinha apontamentos das suas numerosas investigações" e muita da informação publicada foi devido à "sua viva memória", daí que nos restem apenas os textos publicados, os relatórios oficiais redigidos na época e eventuais informações contidas nos cadernos de campo de Abel Viana. Cf. Viana, A. (1950) - Op. cit., p. 289-290.

(10) Paço, Afonso do e Ferreira, Octávio da Veiga (1951) - Antiguidades de Fontalva (Eivas). Revista de Guimarães. Guimarães: Sociedade Martins Sarmento, 61 (3-4), Jul.-Dez., p. 416; Paço, Afonso do; Ferreira, Octávio da Veiga e viana, Abel (1957) - Antiguidades de Fontalva. Neo-eneolitico e época romana. Zephyrus. Salamanca: Universidade de Salamanca, 8 (1), p. 112.

Conimbriga, 37 (1998), 233-265 
nosso exemplar n. $^{\circ} 7$ teria sido fundamental para criar uma nova variante da forma XXXVII da sua tipologia e, simultaneamente, apresentar mais um copo, demonstrativo da importação para a Lusitânia de um produto que consideramos possivelmente de origem galo-romana. Assim, esta investigadora, ou não foi ao Museu, ou as peças não estavam visíveis, ou nem sequer lhe foram mencionadas. O mais provável é não ter tido conhecimento do depósito destes materiais, julgando que a totalidade do espólio conservado se encontrava em Vila Viçosa. Esta situação pressupõe, no entanto, o desconhecimento, por parte da autora, do conteúdo na íntegra de pelo menos dois artigos dos arqueólogos portugueses, publicados na revista $\operatorname{Brotéria}\left({ }^{\mathrm{n}}\right)$, e no III Congresso Arqueológico Nacional(12) espanhol, realizado na Galiza, onde é explicitamente referido que os materiais das necrópoles estão depositados em ambos os museus. Porém, na bibliografia inserida no seu livro, está presente o segundo artigo citado, o que contribui para tomar mais estranha a ausência de qualquer referência às peças de Eivas, reforçando pois a hipótese de um desconhecimento real do texto na sua totalidade, isto devido possivelmente a uma deficiente leitura do artigo. Este facto parece ser comprovado pela seguinte afirmação da autora a propósito do "grand nombre de vases à parois fines" exumados nas "nécropoles de la région d'Elvas", que não deixa lugar a qualquer dúvida: "Ces vases sont conservés aujourd'hui dans le Palais Ducal de Vila Viçosa (...)”(13).

O inventário do Museu Municipal de Eivas não revela todas as informações julgadas convenientes. Assim, verificamos que há dúvidas no registo de uma das peças - a n. ${ }^{\circ} 1$ do nosso catálogo - e desconhecemos a proveniência da peça a que atribuímos o n. ${ }^{\circ}$ 4. Por estar omisso nas publicações dos escavadores, faltam-nos ainda referências exactas às sepulturas a que pertencem. Como se poderá comprovar pela consulta do nosso catálogo, a tentativa de reconstituição pelas descrições e fotografias não permitiu retirar conclusões definitivas.

(n) Viana, Abel (1955) - Notas de Corografia Alentejana. Brotéria: Revista Contemporânea de Cultura. Lisboa: Gaspar Maria Leal Gomes Pereira Cabral. 61(6), p. 551-553.

(12) Deus, António Dias de; Louro, Henrique da Silva e viana, Abel (1955) - Apontamento de estações romanas e visigóticas da região de Eivas (Portugal). In: III Congreso Arqueológico Nacional-Galicia, 1953. Zaragoza: Institución Femando el Católico (Sección de Arqueología) - Secretaría General de los Congresos Nacionales, p. 568-578.

(13) мavet, Françoise (1975) - Les céramiques à parois fines dans la Péninsule Ibérique. Paris: Diffusion E. de Boccard, p. 145.

Conimbriga, 37 (1998), 233-265 
$\mathrm{O}$ estudo destes materiais foi dificultado pelo seu estado de conservação. Quatro aspectos ressaltam de uma análise cuidada. Quando foram exumadas as peças, não foram limpas, e muitas conservaram-se com a terra acumulada no interior durante vários anos, embora actualmente esta situação já não se verifique. As limpezas da década de 50 foram realizadas recorrendo à utilização de ácido. $\mathrm{O}$ uso do canivete fez desaparecer o engobe que cobria as paredes internas e externas. E, nos restauros então efectuados, foi utilizado gesso em grandes camadas. Todas estas situações contribuíram decisivamente para acentuar de forma muito negativa o estado de conservação destas peças.

Quanto à bibliografia, os textos de Abel Viana e António Dias de Deus caracterizam-se por nos esclarecerem sistematicamente relativamente ao tipo de enterramentos identificados — incineração ou inumação. Revelam-se, por um lado, cuidados na descrição da estrutura das sepulturas e, por outro, muito superficiais na descrição do espólio exumado, apresentando meros inventários do conteúdo de cada sepultura. Os artigos tomam-se também interessantes, pelas relações e pelos paralelos culturais e cronológicos que estabelecem entre as necrópoles elvenses escavadas, e outros contextos inclusive estranhos à região do nordeste alentejano. Por outro lado, importa frisar que nem sempre as peças apresentadas são satisfatoriamente descritas ou ilustradas nos apêndices documentais que acompanham os artigos. Quando comparamos os vários textos publicados, verificamos existirem frequentes enganos chegando a atribuir uma mesma peça a sepulturas diferentes, ou duplicar os números de inventário. Não raramente, uma leitura atenta faz parecer que alguns são redigidos por vezes de forma pouco exaustiva, e até durante a realização dos trabalhos de escavação, assemelhando-se, portanto, a cadernos de campo vertidos para letra de forma. Constatamos, ainda, que os artigos sucedem-se no tempo a um intenso ritmo, acumulando inexactidões relativamente à proveniência das peças $\left({ }^{14}\right)$.

${ }^{(14)}$ Curiosamente, a situação que acabamos de descrever tem algumas explicações que nos são dadas pelo próprio Abel Viana. Nos casos em que as escavações foram realizadas apenas contando com a presença de António Dias de Deus, os textos redigidos por ambos sobre essas realidades reflectem algumas falhas e trocas de espólio, apresentando-se, de uma maneira geral, qualitativa e quantitativamente mais pobres. Com a colaboração activa de Abel Viana nos trabalhos de campo a partir de 1949, e até à morte de António Dias de Deus em 24 de Abril de 1955, os artigos que tratam os novos sítios identificados e escavados tomam-se mais ricos e pormenorizados do ponto de vista informativo. Aliás, a publicação de textos inicia-se e decorre intensa exactamente 
São também praticamente inexistentes as informações complementares que permitem ligar estas necrópoles com os locais de habitat das populações romanas, embora se possam avançar alguns dados nesse sentido. Aliás, os próprios escavadores, em algumas passagens dos seus artigos, estabelecem relações entre sítios com diferentes funções. Certo é que devemos relacionar estas necrópoles, e as dezenas de uillae já identificadas até ao presente momento no actual concelho de Eivas, a partir de uma cuidada análise da distribuição espacial dos arqueossítios, assente numa prospecção arqueológica exaustiva do território.

Por último, importa referir que com o recurso aos métodos de análise química e petrográfica se poderão obter mais informações no que diz respeito a uma mais eficaz caracterização das pastas dos vários recipientes deste corpus e, portanto, das origens da peça n. ${ }^{\circ}$ 7. Devido a limitações de tempo e meios, essa hipótese de trabalho é por nós conscientemente deixada em aberto.

\section{Breve descrição dos sítios arqueológicos de onde são provenientes as peças que integram o corpus e das escavações ali realizadas}

Parece-nos relevante, num trabalho com estas características, - estudo de um conjunto de materiais exumados por outros, em que se pretende também reconstituir realidades, vicissitudes e itinerários inerentes à investigação então efectuada -, elaborar uma muito breve apresentação dos sítios arqueológicos de onde são provenientes as peças que integram o nosso corpus, com base na leitura da bibliografia disponível. Este esboço permitirá ilustrar os sítios, os contextos então identificados e, até, avivar um pouco a nossa memória colectiva para a história das descobertas, por vezes essencial para compreender determinado tipo de processos de trabalho e conclusões avançadas.

a partir do momento em que se estabelece a colaboração entre estes dois investigadores, resultado de uma acção prévia de mediação de Domingos Lavadinho, então Director do Museu e Biblioteca Municipal de Eivas, que muito provavelmente reconheceu a importância do momento que se vivia na Arqueologia elvense e a necessidade de agregar um arqueólogo profissional, de méritos firmados, com trabalho desenvolvido e interesse pela região. Cf. Vıana, A. (1950) - Op. cit., 589-590 e Idem (1956) - Algumas notas sobre António Dias de Deus e as suas pesquisas arqueológicas no concelho de Eivas. Beja: Ed. de autor. 
As cerâmicas de paredes finas em estudo remetem-nos para três sítios arqueológicos exactos, concretamente duas necrópoles localizadas na Herdade do Padrão e na Horta das Pinas, que foram parcialmente escavadas por Abel Viana e António Dias de Deus. O sítio arqueológico romano que se localiza na Herdade de Fontalva, e ao qual pertence uma das peças, pode também ser caracterizado como tratando-se de uma necrópole, pois embora Abel Viana em conjunto com outros dois arqueólogos - Afonso do Paço e Octávio da Veiga Ferreira - não tenham procedido a escavações, e tendo apenas estudado um conjunto de materiais recolhido em condições muito incertas, referem, explícitamente num artigo, tratar-se de materiais provenientes de sepulturas. Pela análise do inventário dos materiais publicados parece poder antever-se a existência de uma área de habitat, possivelmente uma uilla, onde deverão ter sido recolhidos alguns dos artefactos. Uma das peças do nosso corpus, de proveniência desconhecida, deixa porém em aberto a hipótese de pertencer a um dos sítios em questão, ou a um outro dos muitos existentes no concelho de Eivas, que estes investigadores, ou outros, escavaram ou visitaram em prospecção.

De seguida apresentam-se sumariamente estes sítios e remetem-se para notas os textos mais importantes que se lhes referem.

\section{Necrópole da Horta das Pinas( $\left.{ }^{15}\right)$ - Localiza-se na freguesia de}

S. Vicente e Ventosa. Foi descoberta pelos "rapazitos do sítio" e pelos "pequenos pastores" que ali "costumavam escavar o solo, a fim de obterem loiças para seus brinquedos"(16). O sítio foi escavado por Abel Viana e António Dias de Deus entre Março e Agosto de 1950. Foram identificadas 61 sepulturas de incineração. Os arqueólogos referem que se trata apenas de uma parte da necrópole. Do ponto de vista da estrutura tumular, as sepulturas podem ser agrupadas em dois grandes grupos génericos: o simples covacho - com cerâmica e outros objectos pessoais, bem como cinzas - , coberto com algumas pedras de pequena dimensão; ou um covacho revestido e coberto por lajes ou tegulae. Só foram detectados contextos de incineração. O espólio exumado é constituído por peças de cerâmica comum, terra sigillata, cerâmica de paredes finas,

(15) Deus, A. D. de; Louro, H. da S. e viana, A. (1955) - Op. cit., p. 570; viana, A. (1955) - Op. cit., p. 552-553; viana, A. e Deus, A. D. de (1950) - Op. cit., p. 242-244; Idem (1953) - Op. cit., p. 70-71; Idem (1956) - Op. cit., p. 143-154.

(16) Viana, A. e Deus, A. D. de (1956) - Op. cit., p. 142. 
vidros, fíbulas e fivelas de bronze e outros objectos metálicos e de adorno.

As sepulturas foram datadas pelos escavadores como pertencendo a um período que vai do início do séc. I a C. ao final do séc. II d. C.

Necrópole da Herdade do Padrão $\left({ }^{17}\right)$ - Localiza-se na freguesia de Salvador, Ajuda e Santo Ildefonso. Foi descoberta acidentalmente em Setembro de 1948, ao proceder-se à abertura de uma estrada. Na ocasião estes trabalhos afectaram 5 sepulturas, das quais se recolheram apenas quatro recipientes cerâmicos. Abel Viana e António Dias de Deus procederam ali a escavações entre Novembro de 1949 e Dezembro de 1950, tendo identificado mais 17 sepulturas. Todas as sepulturas eram de incineração. Apresentava túmulos de construção muito rudimentar - simples covachos protegidos com pedras -, no interior dos quais eram depositadas as urnas $\mathrm{e}$ as cinzas. Os túmulos mais elaborados eram rectangulares formados por tegulae ou lajes de xisto. O espólio exumado, muito variado, é composto por cerâmica comum, terra sigillata, cerâmicas de paredes finas, lucernas, vidros e objectos metálicos incluindo de adorno.

Os escavadores propõem uma cronologia que vai do início do século I d. C. até aos meados do séc. III.

Necrópole (?) da Herdade de Fontalva( $\left.{ }^{18}\right)$ - Situa-se na freguesia de Santa Eulália. Trata-se de um sítio arqueológico que se presume ser muito extenso, e se situa, muito provavelmente, na elevação junto ao "Monte" dos proprietários da Herdade, embora se desconheça o local exacto onde se realizaram as sucessivas recolhas de materiais. Pela análise do conteúdo de dois textos publicados sobre os materiais provenientes dessas colectas ocasionais - e, eventualmente, de escavações -, realizadas fundamentalmente pelo proprietário Rui de Andrade, pode concluir-se que se trata de uma necrópole, visto que é referido de forma clara que os materiais são provenientes de "sepultura" ou "que se estuda um conjunto funerário". Contudo, não se pode aferir o número exacto de sepulturas então descobertas.

(17) Deus, A. D. de; louro, H. da S. e viana, A. (1955) - Op. cit., p. 569-570; Viana, A. (1955) - Op. cit., p. 551-552; viana, A. e Deus, A. D. de (1950) - Op. cit., p. 236-242; Idem (1953) - Op. cit., p. 70; Idem (1956) - Op. cit., p. 138-141.

(18) Paço, A. do e Ferreira, O. da V (1951) - Op. cit., p. 416-425; Paço, A. do; ferreira, O. da V e viana, A. (1957) - Op. cit., p. 111-133.

Conimbriga, 37 (1998), 233-265 
De acordo com os relatos e as descrições dos materiais publicados pelos vários arqueólogos parece, no entanto, que alguns dos artefactos serão estranhos ao ambiente de necrópole, podendo então as recolhas ter incidido sobre áreas de habitat, sobrepostas ou existentes nas proximidades.

De acordo com o que nos é referido nos textos citados, os materiais indicam uma ocupação que abarca os séculos I a IV d. C. Octávio da Veiga Ferreira, a partir da análise correlacionai efectuada com os outros materais encontrados numa sepultura a que pertence a lucerna que publica, aponta o séc. IV como cronologia para o enterramento.

Parece-nos, também, óbvio que a descoberta de materiais romanos na Herdade de Fontalva, embora contemporânea das restantes escavações e prospecções realizadas nesta época, no concelho de Eivas, não se enquadra na mesma linha de estudo e divulgação, visto que na eventual necrópole aí existente nunca decorreram — que se tenha notícia escavações, por parte dos investigadores alentejanos que ali trabalhavam diária e intensamente, designadamente António Dias de Deus, a que se juntou Abel Viana entre 1949 e 1955. Sabendo do interesse que este tipo de realidades despertou nestes arqueólogos, para as quais orientaram, nos meados deste século, todas as suas atenções, é difícil compreender as razões que os afastaram de "dar a conhecer" mais uma "necrópole céltico-romana". Este facto pode ser explicado pelo eventual interesse e zelo do proprietário, que, apesar de oferecer o espólio ao Museu dos Serviços Geológicos, e permitir o seu estudo, afastaria estes arqueólogos, chamando a si a realização de algumas sondagens no terreno, que aparentemente não ficaram documentadas. Estranho é, também, a Herdade de Fontalva estar ausente das listagens de estações romanas publicadas por Abel Viana e António Dias de Deus na mesma época, quando já se conhecia a existência destes vestígios. Nos dois artigos que consultámos dedicados ao estudo dos materiais romanos da Herdade de Fontalva $\left({ }^{19}\right)$, só Abel Viana participa, e no segundo datado de 1957. António Dias de Deus, residente em Vila Fernando e principal impulsionador dos trabalhos desta dupla de arqueólogos na região de Eivas, faleceu em 1955, o que poderá constituir a principal razão que o impediu de eventualmente vir a ser co-autor daquele artigo. $\mathrm{O}$ seu

(19) PaÇO, A. do e Ferreira, O. da V. (1951) - Op. cit. I PAÇO, A. do; Ferreira, O. da V. e VianA, A. (1957) - Op. cit.

Conimbriga, 37 (1998), 233-265 
desaparecimento pode ainda explicar o facto de não ter havido escavações prioridades de estudo, inclusive bem distantes da região de Eivas.

Os materiais recolhidos foram depositados pelo proprietário da Herdade no Museu dos Serviços Geológicos, em Lisboa, onde actualmente se encontram $\left({ }^{20}\right)$.

Nessa medida, desconhecemos em absoluto se a peça estudada - e outras existentes no Museu Municipal de Eivas - pertence ao mesmo conjunto, ou se foi recolhida em outra ocasião. Sobre os autores das recolhas e os contextos nada podemos referir neste momento.

\section{Análise do corpus}

O conjunto em estudo, constituído pelas sete peças de cerâmica de paredes finas existentes no Museu Municipal de Eivas, caracteriza-se, essencialmente, por revelar uma grande homogeneidade quanto ao tipo representado e à sua origem, com excepção para a peça n. $^{\circ} 7$ do nosso catálogo.

As peças n.os 1 a 6 pertencem, pelo tipo de pasta, pela forma e pela decoração, à denominada produção emeritense definida, pela primeira vez, por Françoise Mayet, no seu livro sobre as cerâmicas de paredes finas da Península Ibérica(21).

Neste corpus estão representadas taças carenadas, - com e sem asas -, com a parte superior da pança ligeiramente inclinada e encurvada para o interior, normalmente apresentando um lábio boleado. A carena que divide a pança, em metade superior e inferior, é salientada por uma larga canelura - por vezes duas. A base é sempre constituída por um pequeno pé, geralmente côncavo.

Por todas estas características, as peças em estudo são incluídas na forma MAYET XLIII e na sua variante XLIII A, neste último caso quando existem duas asas.

Quanto à decoração, verificamos que o tipo mais utilizado é o da técnica de guilhoché, presente em quatro das peças estudadas. Este é aplicado normalmente em duas bandas separadas por uma fina ranhura, e executado apenas na parte superior da pança, o que é uma constante na produção de paredes finas com origem em Mérida, para este tipo de taça.

${ }^{(20)}$ Idem - Ibidem, p. 416; e Idem - Ibidem, p. 112.

$\left.{ }^{21}\right)$ MAYET, E (1975) - Op. cit., p. 142-147.

Conimbriga, 37 (1998), 233-265 
Embora tendo presente as limitações impostas pela exiguidade da nossa colecção, parece-nos relevante referir que os sítios arqueológicos que forneceram estas peças apresentam produtos originários da Lusitânia, facto que contribui para reforçar a tese de que os territórios circundantes da capital da província - Augusta Emerita - eram abastecidos fundamentalmente por este centro produtor, durante o primeiro século da nossa era, em detrimento das áreas de produção localizadas na Bética(22).

No que diz respeito às cronologias que Abel Viana e António Dias de Deus apresentaram para as necrópoles da Herdade do Padrão e Horta das Pinas, como tendo sido também utilizadas ao longo da segunda metade do séc. I d.C, pode concluir-se, pelo estudo das cerâmicas de paredes finas exumadas nessas necrópoles, que se confirmam, para a época mais antiga, as datações avançadas pelos autores( $\left.{ }^{23}\right)$. Mayet, por seu lado, sem esquecer os resultados obtidos nas escavações efectuadas no território da Lusitânia, opta por afinar as cronologias que atribui a esta forma apenas por um exemplar encontrado em Munigua (Mulva)(24) que foi, em primeiro lugar, apresentado por Mercedes Vegas, como exemplo do seu tipo 34.d ("tazas con decoración a la barbotina")(25), e atribuído ao periodo NeroFlaviano. Possivelmente por considerarem que a cronologia atribuída aos enterramentos onde foram exumadas estas taças de cerâmica de paredes finas continha um intervalo de tempo excessivamente lato, ambas as autoras não tiveram em conta os resultados dos arqueólogos portugueses ao estabelecer as cronologias definitivas para a forma em questão.

A peça que falta aqui analisar, e que tem no nosso catálogo o . $^{\circ} 7$, é proveniente da necrópole da Horta das Pinas e levanta problemas, não quanto à sua classificação formal, mas sim no que diz respeito ao local de produção.

A forma hemisférica que apresenta permite defini-la como uma peça da forma MAYET XXXVII. Porém, a decoração do tipo “depressão"(26), obtida possivelmente através da pressão efectuada pelo polegar do oleiro na pança, enquanto o barro ainda estava fresco,

(22) Idem - Ibidem, p. 142-147.

(23) VianA, A e DeUs, A. D. de (1950) - Op. cit., p. 247-253.

(24) MAYET, F. (1975) - Op. cit., p. 89.

(25) Vegas, Mercedes (1973) — La cerámica común romana del Mediterráneo Ocidental. Barcelona: Universidad de Barcelona-Instituto de Arqueologia y Prehistoria, Col. Publicaciones Eventuales n. ${ }^{\circ} 22$, p. 80-85, fig. 27.

${ }^{(26)}$ Este tipo de decoração é bastante utilizado pelos oleiros do Norte do Império 
toma-a ausente do repertório, quer da produção de Mérida, quer das produções típicas da Bética. A decoração do tipo "depressão" nas cerâmicas romanas parece ser inspirada pelas peças metálicas de prata, com cronologias dadas pelo tesouro da Casa do Menandro, em Pompeia (75 a. C. a 25 a. C.). No entanto, também foram encontrados copos em cerâmica no enterramento $\mathrm{n}^{\circ} 34$ (incineração) da necrópole de Las Cortes (Ampurias), com datações entre 100 e 50 a. C., na basílica Julia (Roma) de época pré-tiberiana e em Lindenhof (Zurique) de cronologia alta( $\left.{ }^{27}\right)$, o que necessariamente faz recuar a data de utilização deste tipo de motivo decorativo nas cerâmicas e pode indiciar outro tipo de filiação.

Segundo Maria Grazia Maioli(28), que num estudo sobre cerâmica de paredes finas da área de Ravena faz referência a dois exemplares com o mesmo tipo de decoração, apresentando apenas o desenho de uma taça (carenada?) ${ }^{29}$ ), informa-nos que a peça imita modelos de vidro (ISINGS 32 com cronologias da $2^{\text {a }}$ metade do séc. I d. C.), dando a autora uma datação “dalla metà del $1 .^{\circ}$ sec. d. C.." $\left({ }^{30}\right)$. Menciona, também, a possibilidade de esta forma ter origem no repertório de copos metálicos helenísticos) ${ }^{31}$ ).

Abel Viana e António Dias de Deus descreveram e classificaram esta peça como sendo "Uma de barro branco, pintada. Tem forma esferoidal

Romano, especialmente os da Britânia (caso das olarias do vale de Nene, Oxford e Stanground, durante todo o séc. II e III d. C.) influenciados pelas produções gaulesas de Lezoux e do limes renano. Cf., entre outros, BROWN, A. E. e WoOdFIELD, Charmian (1983) - Excavations at Towcester, Northamptonshire: The Alchester Road Suburb. Northamptonshire Archaeology. Northamptonshire: s. ed., 18, p. 74-110; DANNELL, G. B.; HARTLEY, B. R.; Wild, J. R e PerRIN, J. R. (1993) - Excavations on a RomanBritish pottery production site at Park Farm, Stanground, Peterborough, 1965-1967. Journal of Roman Pottery Studies. Oxford: Oxbow Books, voi. 6, p. 51-93.

(27) MAIURI, A. (1933) - La Casa del Menandro e il suo tesoro di argentana. Roma: s. ed., n. ${ }^{\circ} 106-109$, p. 371-372, fig. 146, citado em: MOEVS, Maria Teresa Marabini (1973) - The Roman thin walled pottery from Cosa (1948-54). Roma: American Academy in Rome. Col. Memories of the American Academy in Rome, voi. 32, p. 80 e 86. Cf., também, MAYET, F. (1975) - Op. cit., p. 37.

(28) MAIOLI, Maria Grazia (1972-73) — Vasi a pareti sottili grigie dal Ravennate. Rei Cretariae Romanae Fautorum Acta. Ravena: s. ed., 14-15, p. 110 e 119.

(29) Idem — Ibidem, p. 114.

$\left({ }^{30}\right)$ Considera a peça de vidro rara na área de Ravena, mas presente em todas as regiões da bacia do Mediterrâneo, enquanto que a forma de cerámica de paredes está atestada até em contextos arqueológicos de Inglaterra. Cf. Idem — Ibidem, p. 110.

(31) Idem - Ibidem, p. 117, nota 12. 
amolgada em quatro lados opostos dois a dois, mostrando cada uma destas faces uma larga cavidade"( ${ }^{32}$ ). Embora citando estes autores, F. Mayet possivelmente não relacionou esta descrição com um copo de cerâmica de paredes finas, estando a peça omissa no seu catálogo( $\left.{ }^{33}\right)$.

Não podendo enquadrar esta peça nas produções ibéricas, procurámos encontrar paralelos nas produções galo-romanas: Lyon - concretamente em La Butte - e La Graufesenque $\left.{ }^{34}\right)$.

Convém desde já fazer notar que uma característica que parece ser atributo fundamental dos exemplares galo-romanos - a decoração de granitado arenoso - não existe no copo proveniente da necrópole da Horta das Pinas, o que pode ter resultado das condições de deposição e do tipo de limpeza quando dos vários restauros efectuados, que devem ter contribuído para destruir o engobe e a decoração que muito possivelmente teria.

No que diz respeito à produção da Gália Central, embora as duas pastas se possam comparar - pouco homogéneas, de cor clara e nunca camurça ou castanha, brandas e progressivamente desagregáveis, quando em contacto prolongado com os agentes químicos dos solos -, parecemos que, no aspecto formal, o pequeno copo da Horta das Pinas e os copos lioneses são diferentes. A forma GREENE tipo 21 (35) que poderia servir de paralelo por exibir depressões na pança e bordo extrovertido, apresenta, no entanto, um ombro redondo e alto, que a afasta do nosso exemplar.

Porém, uma breve passagem de um artigo de F. Mayet( $\left.{ }^{36}\right)$ reforça a possibilidade de filiar a peça nestas produções da Gália Central. Embora

(32) VianA, A. e DeUS, A. D. de (1956) - Op. cit., p. 181.

(33) MAYET, F. (1975) - Op. cit.

(34) BÉMONT, Colette (1976) - Vases à parois fines de Glanum: formes et décors. Gallia. Paris: Centre National de la Recherche Scientifique. 34 (1), p. 237-238, 260, 262 (n. ${ }^{\circ}$ 7536); GREENE, Kevin. (1979) - The Pre-Flavian fine ware. Report on the excavations at Usk, 1965-1976. Cardiff: University of Wales Press, p. 13-27 e 50-55; MAYET, F. (1980) — Les céramiques à parois fines: état de la question. In: Céramiques Hellénistiques et Romaines. Paris: Centre de Recherches d'Histoire Ancienne, vol. 36, p. 209-211 ; MINGUEZ MORALES, José Antonio (1991) — La cerámica romana de paredes finas: generalidades. Universidade de Zaragoza: Departamiento de Ciências de la Antiguidad, p. 70-77. RICCI, Andreina (1985) - Ceramica a pareti sottili. In: Atlante delle forme. Ceramiche. Il - Ceramica fine romana nel bacino Mediterraneo (Tardo Ellenismo e Primo Imperio). Roma: Istituto della Enciclopedia Italiana, p. 350-352.

( $\left.{ }^{35}\right)$ GREENE, K. (1979) - Op. cit., p. 24, fig. 8.

(36) MAYET, F. (1980) - Op. cit., p. 209.

Conimbriga, 37 (1998), 233-265 
apresentando uma definição curta e incompleta - pois descreve apenas a parte superior da pança e a respectiva decoração — , e sem estar apoiada em qualquer ilustração deste tipo de copo pequeno, a autora descreve-nos os gobelets de Lyon como possuindo um bordo com lábio extrovertido e separado da pança por uma fina ranhura, o que permite visualizar algumas semelhanças com o exemplar proveniente da Horta das Pinas.

Nesta busca existem, pois, pistas de sinal contrário. Se o tipo 21 de K. Greene se afasta definitivamente pelas razões apontadas, a descrição de F. Mayet pode fazer-nos estabelecer o paralelo e, consequentemente a origem desta produção, ainda que nos coloque reservas.

Os produtos que oferecem as olarias de La Graufesenque parecem-nos, porém, ser passíveis de comparação. Um exemplar classificado como sudgálico e proveniente das escavações de Ampurias (L'Escala)( ${ }^{37}$ ) apresenta características morfológicas que o definem como um paralelo quase perfeito, bem como um outro recolhido em Usk, no País de Gales( $\left.{ }^{38}\right)$. Para evidenciar melhor esta similaridade apresentamos, seguidamente, um quadro no qual se comparam apenas os copos da Horta das Pinas e a de L'Escala, concretamente quanto às dimensões (em milímetros), ao tipo de pasta e ao engobe, pois não foi possível obter dados quantitativos para o exemplar galês.

\section{Quadro 1}

\begin{tabular}{|c|c|c|c|c|c|c|}
\hline \multirow{2}{*}{ PEÇA } & \multicolumn{2}{|c|}{ DIÂMETRO } & \multirow{2}{*}{ ALTURA } & \multirow{2}{*}{ ESP. } & \multirow{2}{*}{ PASTA } & \multirow{2}{*}{ ENGOBE } \\
\hline & Boca & Base & & & & \\
\hline $\begin{array}{l}\text { Horta das Pinas } \\
\text { (MNE - 2942) }\end{array}$ & 82 & 35 & 69 & 2 & $\begin{array}{l}\text { Ocre esbranquiçado } \\
\text { (íOY 8/3) }\end{array}$ & $\begin{array}{l}\text { Alaranjado } \\
\text { (5YR 5/8) }\end{array}$ \\
\hline $\begin{array}{l}\text { L'Escala } \\
\text { (1814) }\left({ }^{*}\right)\end{array}$ & 81 & 32 & 86 & 1,9 & Amarelada & $\begin{array}{l}\text { Alaranjado } \\
\text { (Possivelmente) }\end{array}$ \\
\hline
\end{tabular}

(*) Número de inventário do espólio cerâmico de L'Escala, apresentado por Lopez Mullor (1990), voi. 1, p. 488 (n. $\left.{ }^{\circ} 183\right)$; voi. 2, lam. 24.2.

(37) LOPEZ MUllor, Alberto (1990) - Las cerámicas romanas de paredes finas en Cataluña. Zaragoza: Libros Pórtico, vol. 1, p. 463-466, 488 (n. ${ }^{\circ} 183$ ); vol. 2, lamina 24.2.

(38) GreENE, K. (1979) - Op. cit., p. 51, fig. 21.9. 
Se excluirmos a diferença, bastante significativa, na altura total, parece-nos poder afirmar que as duas peças serão provenientes das olarias de Millau (La Graufesenque) ou do Tam (Montans).

Reforça-se, assim, a hipótese que um de nós (E. S.) defende de uma maior importação, consumo e difusão das cerâmicas de paredes finas galo-romana, na Península Ibérica( $\left.{ }^{39}\right)$, do que aquela que tem sido atestada pelos arqueólogos.

A concentração de exemplares identificados como sudgálicos ao longo do Guadiana - concretamente da área urbana de Mértola, Represas (Beja) e Horta das Pinas (Eivas) — leva a supor da existência de um ponto redistributivo para aquela zona da Lusitânia no actual território português.

O sítio arqueológico das Represas (Beja) tem sido apontado por vários autores, nomeadamente por Jorge de Alarcão( ${ }^{40}$ ) e Maria da Conceição Lopes $\left({ }^{41}\right)$, como sendo o local onde se deveria ter localizado um entreposto comercial de cerâmicas finas incluindo terra sigillata itálica, sudgálica, hispânica e clara - embora esta em quantidades proporcionalmente inferiores. As cronologias apresentadas por Conceição Lopes como "floruit" para as Repressas - o séc. I d. C. - , são compatíveis com a cronologia atribuída ao copo n. $^{\circ} 7$ do nosso catálogo, exumada na necrópole da Horta das Pinas, o que leva a considerar a possibilidade de terem existido "intermediários" que, depois de se abastecerem naquela uilla percorriam o interior da Lusitânia( $\left.{ }^{42}\right)$, fornecendo aos consumidores cerâmica de paredes finas de origem gaulesa.

À margem de todo este cenário, duas outras hipóteses que nos parecem plausíveis podem ainda ser levantadas, para explicar a origem da produção deste pequeno copo, baseadas na possibilidade de a sua pasta ser considerada como afim das da Bética.

(39) SEPÚlVEDA, Eurico - Cerâmica romana de paredes finas de Troia (Setúbal-Portugal). (em preparação).

$\left({ }^{40}\right)$ ALARCÃO, Jorge de (1990)—A produção e circulação de produtos. In: SERRÃO, Joel e MARQues, A. H. de Oliveira (Dir.) - Nova História de Portugal. Lisboa: Editorial Presença, voi. 1, p. 435.

(41) LOPES, Maria da Conceição (1994) - A Sigillata de Represas — Tratamento Informático. Coimbra: Universidade de Coimbra-Faculdade de Letras-Instituto de Arqueologia, Coi. Conimbriga/Anexos n. ${ }^{\circ}$ 2, p. 103-106.

${ }^{(42}$ ) Nolen, Jeannette U. Smit (1994) - Cerâmicas e Vidros de Torre de Ares Balsa. Lisboa: Instituto Português de Museus-Museu Nacional de Arqueologia, p. 56 , est. 8 , pf-5.

Conimbriga, 37 (1998), 233-265 
Assim, podíamos estar perante a estilização da forma MAYET VII por oleiros da Bética, tendo sido produzida nesta província; ou poderia tratar-se da cópia de modelos sudgálicos, também efectuada pelos mesmos.

No que respeita à primeira hipótese, esta radica no facto de ambas as peças apresentarem uma forma similar, embora o bordo e o colo da peça da Horta das Pinas apresentem um perfil mais "elegante" do que aqueles que são desenhados por F. Mayet, concretamente o exemplar n. ${ }^{\circ}$ 88, proveniente da necrópole de las Cortes (Ampurias)( $\left.{ }^{43}\right)$, no qual existe uma forte descontinuidade entre o bordo e a pança. Relativamente à cópia dos modelos sudgálicosC ${ }^{44}$ ), baseamo-nos no que expusemos nos parágrafos anteriores, e na comparação efectuada com o exemplar de L'Escala também ampuritana $\left({ }^{45}\right)$. F. Mayet apresenta, para a produção emeritense, a possibilidade de existir uma justaposição desta com as produções de cerâmica fina galo-romanas (Lyon), o que poderia possivelmente também ter acontecido na Bética.

Seguindo a mesma lógica de arrumação tipológica que a autora propôs, consideramos que o nosso copo constitui uma nova sub-variante da forma MAYET XXXVII a qual poderíamos denominar de MAYET XXXVII A/Ba (em que "a" representa a decoração do tipo depressão).

\section{Breves considerações preliminares acerca das formas de cerâmicas de paredes finas presentes simultaneamente no espólio da Villa Romana da Quinta das Longas e das necrópoles da Herdade do Padrão, Horta das Pinas e Herdade de Fontalva}

No presente momento em que redigimos este artigo, encontramo-nos a preparar um estudo sobre o conjunto de cerâmicas de paredes

(43) MAYet, F. (1975) - Op. Cit., p. 38, pi. XI, n. ${ }^{\circ} 88$.

O Sobre cerâmicas de paredes finas de origem sudgálica em Portugal, podem ser consultadas as obras que seguidamente se indicam. Em cada artigo está presente apenas um exemplar; na última referência a forma proposta é uma HERMET 9 (vasos decorados): RiBEIRO, F. N. (1956) - Op. cit., p. 19-20; MAYET, Françoise (1976) - Céramiques à parois fines. In: ALARCÃO, Jorge de e ÉTIENNE, Robert (Dir.) - Fouilles de Conimbriga. VI - Céramiques Diverses et Verres. Paris: Diffusion E. de Boccard, vol. 6, p. 37, planche VUI, n. ${ }^{\circ}$ 84; NOLEN, J. U. S. (1994) - Op. cit., p. 56, est. 8, pf-5 e SEPÚLVEDA, E. - Op. cit..

${ }^{(45)}$ LoPeZ Mullor, A. (1990) - Op. cit., vol. 1, p. 463-466, 488 (n. ${ }^{\circ} 183$ ); vol. 2, lamina 24 . 
finas exumado nas cinco campanhas de escavações já realizadas na uilla romana da Quinta das Longas $\left({ }^{46}\right)$.

O estado dessa investigação implica que estamos na posse de uma quantidade substancial de dados coligidos nas análises que efectuámos aos fragmentos cerâmicos recolhidos. Sem querer antecipar a apresentação do estudo e do catálogo de materiais ou as respectivas conclusões, pareceu-nos oportuno cruzar e comparar a informação proveniente das nossas escavações com a informação deste corpus, nomeadamente quanto ao número de peças das formas representadas.

$\mathrm{O}$ quadro que preparámos e que apresentamos seguidamente pretende agrupar toda a informação relativa à forma mais representada $\left({ }^{47}\right)$ no espólio exumado na uilla romana da Quinta das Longas - MAYET XLIII e XLIIIA - e outras - MAYET XXXVII e XLIV, as quais estão também presentes no corpus estudado neste artigo. Estas últimas foram agrupadas por necrópole e, dentro destas, por local de depósito. Comparamos naturalmente o número de exemplares de cada forma e não o número de fragmentos cerâmicos. Pretendemos tão só mostrar dados quantitativos arrumados por formas e por locais de proveniência e depósito, e daí retirar algumas breves ilações.

(46) Carvalho, António e Sepúlveda, Eurico - A Villa Romana da Quinta das Longas (S. Vicente e Ventosa, Eivas): As Cerâmicas Romanas de Paredes Finas, (em preparação).

$\left.{ }^{(47}\right)$ Embora neste quadro a forma com maior número de recipientes é a MAYET XT ITT, importa referir, que em todo o conjunto cerâmico exumado na uilla romana da Quinta das Longas, a forma MAYET LUI é, de longe, a forma mais representada por exemplares bem definidos. Mas também na Quinta das Longas as formas MAYET XLIII/ XLIV registam um número de fragmentos que inevitavelmente determinariam um maior número de recipientes. 
Quadro 2

\begin{tabular}{|l|l|l|l|l|l|l|l|l|}
\hline $\begin{array}{l}\text { FORMAS (a) } \\
\text { (MAYET) }\end{array}$ & \multicolumn{7}{|c|}{ SíTIOS } \\
\hline & $\begin{array}{l}\text { Quinta das } \\
\text { Longas }\end{array}$ & \multicolumn{2}{|c|}{$\begin{array}{l}\text { Herdade do } \\
\text { Padrão }\end{array}$} & $\begin{array}{l}\text { Horta das } \\
\text { Pinas }\end{array}$ & $\begin{array}{l}\text { Herdade de } \\
\text { Fontalva }\end{array}$ & $\begin{array}{l}\text { Proveniência } \\
\text { Desconhecida }\end{array}$ & $\begin{array}{l}\text { Total/ } \\
\text { Forma }\end{array}$ \\
\hline & & $\begin{array}{l}\text { MME } \\
\text { (f) }\end{array}$ & $\begin{array}{l}\text { PDVV } \\
\text { (b) }\end{array}$ & $\begin{array}{l}\text { MME } \\
\text { (f) }\end{array}$ & $\begin{array}{l}\text { PDVV } \\
\text { (b) }\end{array}$ & $\begin{array}{l}\text { MME } \\
(\mathrm{f})\end{array}$ & $\begin{array}{l}\text { MME } \\
\text { (f) }\end{array}$ & \\
\hline XXXVII & 4 & 0 & 0 & 1 & 0 & 0 & 0 & 5 \\
\hline XLIII & 13 & 0 & 1 & 1 & 2 & 1 & $1(\mathrm{e})$ & 19 \\
\hline XLIIIA & (c) & 2 & 1 & 1 & 1 & 0 & 0 & 5 \\
\hline XLIII/XLIV(d) & 11 & 0 & 0 & 0 & 0 & 0 & 0 & 11 \\
\hline $\begin{array}{l}\text { TOTAL/ } \\
\text { SÍTIOS }\end{array}$ & 28 & 2 & 2 & 3 & 3 & 1 & 1 & 40 \\
\hline
\end{tabular}

(a) Apenas se apresentam as formas presentes no corpus em estudo, e simultanemante presentes no espólio da uilla romana da Quinta das Longas.

(b) As peças em questão, depositadas no Museu do Paço Ducal de Vila Viçosa (=PDVV) e provenientes das necrópoles elvenses, foram estudadas e apresentadas por Françoise May et no seu livro Les céramiques a parois fines dans la Péninsule Ibérique. Embora algumas tenham sido referidas com proveniência desconhecida. A comparação dos desenhos da autora com as fotografias dos escavadores, permitiu-nos relacionar as peças e concluir acerca das respectivas proveniências. No catálogo da autora francesa, as peças têm os seguintes números:
n..$^{\circ} \mathbf{5 1 4}$ - Herdade do Padrão - Forma MAYET XLIII
n. ${ }^{\circ} \mathbf{5 3 5}$ - Herdade do Padrão - Forma MAYET XLIIIA
n. ${ }^{\circ} 516$ - Horta das Pinas - Forma MAYET XLIII
n. ${ }^{\circ} 533$ - Horta das Pinas - Forma MAYET XLIIIA
n. ${ }^{\circ} \mathbf{5 5 0}$ - Horta das Pinas - Forma MAYET XLIII

(c) Não se pode calcular qual o número de fragmentos que pertencem a esta forma pois não foi possível exumar nenhum com a ligação da pança à respectiva asa conservada.

(d) Pelas características da pasta e da decoração trata-se de fragmentos que pertencem a uma destas duas formas. Porém, considerando que se trata apenas de fragmentos não nos é seguro distinguir entre ambas.

(e) Não foi possível identificar esta peça nos trabalhos de Abel Viana e António Dias de Deus, pois não foi publicada qualquer fotografia.

(f) Museu Municipal de Eivas (=MME).

O quadro ilustra dois aspectos principais que julgamos relevantes. A forma MAYET XLIII e a sua variante XLIIIA, bem como o "grupo" algo difuso das MAYET XLIII/XLIV, estão bastante bem representados no espólio da uilla romana da Quinta das Longas. $\mathrm{O}$ número de exemplares destas formas, que correspondem a distintos exemplares, constituem, juntamente com a forma MAYET LUI, ausente deste quadro,

Conimbriga, 37 (1998), 233-265 
as formas melhor representadas, em todo o conjunto de cerâmicas de paredes finas da Quinta das Longas. Por outro lado, e no que respeita às peças a que o quadro se refere - total de exemplares de peças de cerâmica de paredes finas exumadas nas necrópoles da Herdade do Padrão, Fontalva e Horta das Pinas —, a forma MAYET XLIII e a respectiva variante XLIIIA aparecem mais bem representadas, com quatro exemplares, no primeiro caso, e cinco no terceiro, registando a Herdade de Fontalva somente um, sendo outro de proveniência desconhecida. Isto é, estas taças correspondem à forma mais bem representada quer na uilla quer nas necrópoles.

Significativa parece ser também a existência na Quinta das Longas, de apenas quatro exemplares da forma MAYET XXXVII, sendo por sua vez também escassa nas necrópoles, registando-se apenas um exemplar, curiosamente na da Horta das Pinas. É de referir que a inexistência de qualquer taça da forma MAYET XLIV registada nas necrópoles poderá, eventualmente, significar que os onze exemplares provenientes da Quinta das Longas e inscritos no quadro agrupados na categoria MAYET XLIII/ XLIV, poderão na sua maior parte pertencer à primeira das formas, ou seja, à MAYET XLIII.

Dois outros aspectos convém também realçar. Em primeiro lugar, ao elaborar este quadro foi possível ainda determinar a origem de todas as peças publicadas por F. MAYET, provenientes destas necrópoles, a partir da comparação dos desenhos que apresenta com as fotografias publicadas nos trabalhos de Abel Viana e Dias de Deus. Apenas uma peça ficou por identificar.

Num outro plano, estas informações permitem-nos estabelecer uma relação, embora ténue, entre as uillae - e concretamente a uilla romana da Quinta das Longas - e as necrópoles romanas - designadamente a da Horta das Pinas. Insistimos nesta relação, pois julgamos conveniente registar a proximidade geográfica existente entre ambos os sítios arqueológicos - Quinta das Longas e Horta das Pinas - e que corresponde a cerca de $2 \mathrm{Km}$, em linha recta, por terreno plano sem qualquer tipo de acidentes no relevo. Esta relação, que nunca foi antes estabelecida, e não pode para já ser comprovada, parece-nos ser uma perspectiva de análise a ter em consideração em futuras investigações de campo, nomeadamente através da realização de um programa de escavações naquela necrópole, bem como a revisão de todo o espólio exumado em meados do século, para posterior comparação com o da uilla romana da Quinta das Longas.

A existência de uma similaridade de formas em ambos os locais 
pode ser um comprovativo de uma acentuada e homogénea dispersão dos materiais dos ateliers de Mérida nesta parcela do território, mas pode cumulativamente significar também uma relação de contemporaneidade e, eventualmente até, de complementaridade funcional entre ambos os sítios.

\section{Conclusões}

O estudo deste pequeno corpus permitiu-nos tirar algumas conclusões que consideramos pertinentes e importantes no quadro do projecto de investigação arqueológica actualmente em curso na uilla romana da Quinta das Longas e, de uma maneira geral, para os estudos que desenvolvemos com vista a um mais completo conhecimento da ocupação romana no território correspondente ao actual concelho de Eivas.

O estudo destas sete peças de cerâmicas de paredes finas correspondeu à publicação na íntegra de um dos tipos de materiais arqueológicos da época romana inéditos existentes no Museu Municipal de Eivas.

Optámos por estudar este pequeno corpus de materiais sem deixar de caracterizar, ainda que sucintamente, os sítios de onde são provenientes e as intervenções que ali ocorreram. As vantagens desta abordagem traduzem-se no facto de as peças poderem ser observadas enquadradas nos respectivos contextos a que pertencem. Reconstituímos os itinerários dos investigadores, sempre na perspectiva de tentar esclarecer todas as vicissitudes que rodeiam a recolha, o depósito e o estudo de materiais arqueológicos, em que a investigação arqueológica praticada em Eivas em meados do século era bastante pródiga.

A atribuição segura do fabrico emeritense a seis das peças estudadas permitiu enquadrar estes sítios na área de influência directa dos ateliers de Mérida com a respectiva assimilação daquelas produções.

A peça 7 do nosso catálogo constitui uma incógnita do ponto de vista da sua origem. É, no entanto, evidente de que se trata de uma forma de cerâmica de paredes finas pouco frequente na Península Ibérica, como aliás reconhecem os especialistas nesta matéria. Provenientes de sítios arqueológicos da Lusitânia, conhecemos apenas cerca de uma dezena de exemplares, o que não contribui para esclarecer em definitivo qual a origem desta produção. Nas hipóteses levantadas deverá residir a resposta 
a esta interrogação de base, sendo bastante plausível, como tentámos demonstrar, atribuir a esta taça uma origem galo-romana.

Pareceu ainda relevante tentar estabelecer um paralelo com as cerâmicas de paredes finas exumadas nas escavações da uilla romana da Quinta das Longas, constituindo assim uma espécie de "anúncio" do estudo que ultimamos. No Quadro 2 sintetizámos as informações já disponíveis, isto é, comparar os quantitativos das formas presentes neste corpus com o número de exemplares das mesmas formas já exumadas na Quinta das Longas, após cinco campanhas de escavações. Dessa comparação resultou o quadro e algumas breves notas marginais.

A presença de vários exemplares da forma MAYET XXXVII - com decoração de granitado arenoso e pastas afins das da B ética permite-nos também avançar com um elemento cronológico seguro para a datação do início da ocupação romana da uilla da Quinta das Longas (Villa I), ou seja, a partir do final da primeira metade do séc. I d. C. Em face dos dados para já disponíveis $\left({ }^{48}\right)$, poderemos localizar a data de implantação desta uilla num momento que, muito provavelmente, se pode situar entre o principado de Cláudio e o início da dinastia dos Flávios, ou seja, algures entre 42 e 69 d. C.

De uma maneira geral e considerando que no panorama da investigação arqueológica nacional o estudo técnico deste tipo de recipientes cerâmicos não ocupa um dos lugares cimeiros no elenco das atenções dos arqueólogos, este nosso contributo visa, essencialmente, acrescentar novos elementos ao quadro de distribuição das diferentes formas de cerâmicas de paredes finas no actual território português e contribuir para uma melhor caracterização da ocupação romana altoimperial no actual concelho de Eivas.

(48) Além deste indicador tipológico e cronológico seguro, possuímos outros, recolhidos nos mesmos contextos estratigráficos, que reforçam esta proposta de datação para a implantação da Villa I, tais como: vários fragmentos pertencentes a diferentes recipientes cerâmicos de terra sigillata sudgálica (Drag. 24/25 e Drag. 15/17) e, possivelmente, terra sigillata itálica tardia (Atlante X). Juntamente com as cerâmicas de paredes finas, são as peças com cronologia mais alta, exumadas até hoje na uilla romana da Quinta das Longas, o que autoriza, para já, a atribuição deste intervalo de tempo para a fixação romana no sítio.

Conimbriga, 37 (1998), 233-265 


\section{Agradecimentos}

À Sr. ${ }^{a}$ Dr. ${ }^{a}$ Vitória Branco, vereadora do Pelouro da Cultura da Câmara Municipal de Eivas, a autorização concedida para a realização do estudo dos materiais romanos do Museu Municipal de Eivas, e ao Sr. Romão Mimoso, técnico de restauro do Museu, pelo apoio prestado durante a nossa estadia na instituição, no Verão de 1995.

\section{CAtálogo}

\section{N. ${ }^{\circ} 1$ - Taça reconstituída em cerca de $1 / 5$ da sua totalidade}

Forma: Taça carenada, biasada, bordo separado da pança por uma ranhura, lábio ligeiramente almendrado. Base com pé em anel ligeiramente côncava. Asas trilobadas. MAYET XLIIIA.

Dimensões: Diâmetros: boca $-106 \mathrm{~mm}$, base $-40 \mathrm{~mm}$. Alturas: total - $73 \mathrm{~mm}$, carena $-38 \mathrm{~mm}$. Espessuras: média - $4 \mathrm{~mm}$, asa $-4,5 \mathrm{~mm}$.

Pasta: Esbranquiçada (10 YR 8/2), pouco homogénea, muito branda e porosa, com fractura não rectilínea.

Cobertura: Externa - Engobe matizado sendo os tons principais o castanho-avermelhado (5YR 5/8) e preto (5YR 3/1), encontra-se muito erodido e alterado em quase toda a peça excluída a parte inferior da pança; Interna

- Engobe matizado de castanho-laranja-escuro (5YR 5/6) e preto (5YR 2.5/1) igualmente muito erodido.

Decoração: Apresenta na parede externa do vaso, na parte superior da pança, decoração do tipo guilhoché e uma larga canelura na carena. O guilhoché é efectuado com recurso a três tipos diferentes. Eivas).

Proveniência: Herdade do Padrão (Salvador, Ajuda e Santo Ildefonso,

Cronologia: Segunda metade do séc. I d. C.

Peça referida em: Viana, A. e Deus, A. M. de (1950) - op. cit., fig. 26, n. ${ }^{\circ}$ 121(.1) e fig. 27, n. ${ }^{\circ}$ 125(.1); Idem (1956) - op. cit., ests $\operatorname{XXIV(.3)~e~}$ $\mathrm{XXV}(.1), \mathrm{n}^{\circ} 224$, Peça exumada, muito provavelmente, na sepultura $\mathrm{n}^{\circ} 15$ (cf. 1950), referida no artigo de 1956 como sepultura $n .^{\circ} 17$; existe ainda a possibilidade de poder ser proveniente da sepultura n. ${ }^{\circ} 11$ (cf. 1950), referida no artigo de 1956 como sepultura n. ${ }^{\circ} 12$.

N. ${ }^{\circ}$ de Inventário: MNE - 2881 (?) (De acordo com o Inventário do Museu).

Conimbriga, 37 (1998), 233-265 


\section{N. ${ }^{\circ} 2$ - Taça reconstituída em 1/4 da totalidade do bordo e em metade da pança ao longo da carena}

Forma: Taça carenada de tamanho grande, biansada. Bordo separado da pança por uma ranhura, lábio almendrado. Base com pé em anel. Asas em fita trilobadas. MAYET XLIIIA.

Dimensões: Diâmetros: boca $-108 \mathrm{~mm}$, base $-40 \mathrm{~mm}$. Alturas: total $-82 \mathrm{~mm}$, carena $-40 \mathrm{~mm}$. Espessuras: média $-4 \mathrm{~mm}$, asa $-5 \mathrm{~mm}$.

Pasta: Esbranquiçada (10YR 8/3), com elementos não plásticos de pequenas dimensões particularmente de origem ferruginosa e possivelmente de cerâmica moída, muito branda, porosa e de fractura irregular.

Cobertura: Externa - Engobe aderente, moderadamente espesso, matisado, sendo os tons principais o laranja (5YR 5/8) e o castanho muito escuro (5YR 2.5/1); Interna - Engobe de características idênticas ao que cobre a parede externa da taça.

Decoração: Apresenta na parede externa uma decoração do tipo guilhoché aplicada em duas zonas da parte superior da pança que estão separadas uma da outra por uma fina ranhura. A carena está decorada por uma larga canelura. $\mathrm{Na}$ parte inferior da pança, e arrancando da carena, observam-se dois traços paralelos e oblíquos executados pela técnica de barbotina que distam entre si $25 \mathrm{~mm}$, sendo um deles maior do que o outro (respectivamente, $47 \mathrm{e} 45 \mathrm{~mm}$ de comprimento), e que terminam junto à base da peça.

Proveniência: Horta das Pinas (S. Vicente e Ventosa, Eivas).

Cronologia: Segunda metade do séc. I d.C.

Peça referida em: Viana, A. e Deus, A. M. de (1950) - Op. cit., fig. 24, n. ${ }^{\circ}$ 99, Idem (1956) - Op. cit., est. V(.3), n. ${ }^{\circ} 40$.

N. ${ }^{\circ}$ de Inventário: $\mathrm{MNE}-2882$

\section{N. ${ }^{\circ} 3$ - Taça reconstituída em cerca de $1 / 3$ na parte superior do bordo e pança}

Forma: Pequena taça carenada, biansada. Bordo esvasado com lábio ligeiramente lanceolado, com uma ranhura de $2 \mathrm{~mm}$ de largura que divide a parte superior da pança em duas zonas desiguais. Asas em fita trilobada. MAYET XLIIIA.

Dimensões: Diâmetros: boca $-86 \mathrm{~mm}$, base $-30 \mathrm{~mm}$. Alturas: total $-58 \mathrm{~mm}$, carena $-29 \mathrm{~mm}$. Espessuras: média $-4 / 5 \mathrm{~mm}$, asa $-4 / 5 \mathrm{~mm}$.

Pasta: Não há possibilidades de distinguir o tom desta visto a peça ter sido recoberta aquando da reconstituição por uma pasta silítica de tonalidade que varia entre o amarelo e o violáceo. Apresenta uma fractura não rectilínea.

Cobertura: Externa - Engobe completamente erodido, com uma

pequena excepção junto ao pé onde apresenta uma pequena mancha amarelada 
(10YR 8/8); Interna - Possivelmente engobada visto se poderem detectar ainda pequenos pontos de difícil identificação quanto à tonalidade provável — laranja-escuro/castanho (?).

Decoração: A parte superior da pança apresenta duas zonas decoradas com guilhoché aplicado verticalmente, mas de tipo diferente.

Proveniência: Herdade do Padrão (S. Salvador, Ajuda e Santo Ildefonso, Eivas).

Cronologia: Segunda metade do séc. I d. C.

Peça referida em: Viana, A. e Deus, A. M. de (1950) - Op. cit., fig. 26, n. ${ }^{\circ} 121(.3)$ e fig. 27, n. ${ }^{\circ} 125(.2)$; Idem (1956) - Op. cit., ests XXIV(.3) e $\mathrm{XXV}(.1), \mathrm{n}^{\circ}$ 225. Peça exumada, muito provavelmente, na sepultura $\mathrm{n} .{ }^{\circ} 15$ (cf. 1950), referida no artigo de 1956 como sepultura $n .^{\circ} 17$; existe ainda a possibilidade de poder ser proveniente da sepultura $\mathrm{n}^{\circ} 11$ (cf. 1950), referida no artigo de 1956 como sepultura $n .{ }^{\circ} 12$.

N. ${ }^{\circ}$ de Inventário: $\mathrm{MNE}-2886$.

\section{N. ${ }^{\circ} 4$ - Taça fragmentada e reconstituída, faltando-lhe cerca de $2 / 3$ do total}

Forma: Taça carenada de pequenas dimensões sem asas. Bordo com lábio boleado limitado por uma fina ranhura. A parte superior da pança está dividida em duas partes, quase iguais, separadas por uma ranhura de $2,5 \mathrm{~mm}$ de largura. Base em anel, ligeiramente côncava. MAYET XLIII.

Dimensões: Diâmetros: boca $-82 \mathrm{~mm}$, base $-35 \mathrm{~mm}$. Alturas: total - $60 \mathrm{~mm}$, carena - $21 \mathrm{~mm}$. Espessura: média - 3,5 $\mathrm{mm}$.

Pasta: Esbranquiçada (7.5YR 8/0) com elementos não plásticos pouco visíveis (vestígios de calcite), ligeiramente folheada, branda, moderadamente porosa, de fractura não rectilínea.

Cobertura: Externa - Engobe bem conservado, possivelmente com brilho - a peça levou um fixador brilhante a seguir ao restauro — matisado nas gamas laranja-amareloavermelhado (5YR 6/8) e preto (2.5YR 2.5/0); Interna

- Engobe pouco visível, visto a peça ter sido exposta a qualquer tipo de combustão, o que alterou todas as suas características originais. Distinguere, no entanto, vestígios de engobe laranja-carregado $(5 \mathrm{YR} 6 / 8)$ e preto $(2.5 \mathrm{YR}$ 2.5/0).

Decoração: A parede externa, na parte superior da pança, é decorada em duas zonas, com guilhoché aplicado vertical e obliquamente. Carena acentuada por uma larga canelura.

Proveniência: Sítio arqueológico não identificado.

Cronologia: Segunda metade do séc. I d. C.

N. ${ }^{\circ}$ de Inventário: $\mathrm{MNE}-2885$.

Conimbriga, 37 (1998), 233-265 


\section{N. ${ }^{\circ} 5$ - Taça fragmentada e colada faltando-lhe cerca de $2 / 3$ da parte su- perior (desde o bordo até à carena)}

Forma: Pequena taça carenada sem asas. Apresenta o bordo separado da parte superior da pança por uma ranhura fina que se encontra a $7 \mathrm{~mm}$ do lábio que é boleado. Base com pé pequeno em anel ligeiramente côncavo. MAYET XLIII.

Dimensões: Diâmetros: boca $-81 \mathrm{~mm}$, base $-32 \mathrm{~mm}$. Alturas: total - $61 \mathrm{~mm}$, carena - $26 \mathrm{~mm}$. Espessura: média $-3 \mathrm{~mm}$.

Pasta: Ocre esbranquiçado (10YR 8/3) pouco homogénea, ligeiramente folheada, branda, muito porosa e de fractura não rectilínea.

Cobertura: Externa - Devido ao tipo de limpeza efectuada sobre a parede exterior não se consegue detectar qualquer tipo de engobe. No entanto, na parte de apoio da base anel, detecta-se uma ligeira mancha de um engobe alaranjado (possivelmente 5YR 5/6); Interna - O mesmo tipo de observação aplica-se para a parede interior da taça, detectando-se pequenas manchas de engobe da mesma tonalidade da identificada para a parede externa.

Decoração: Parede externa decorada pela técnica de barbotina com grandes lúnulas que ocupam a parte compreendida entre a ranhura que separa o bordo da pança e a carena. O número de lúnulas poder-se-á calcular aproximadamente em 6 . A carena é acentuada por uma larga canelura.

Proveniência: Herdade de Fontalva (Barbacena, Eivas).

Cronologia: Segunda metade do séc. I d. C.

N. ${ }^{\circ}$ de Inventário: $\mathrm{MNE}-2883$.

\section{N. ${ }^{\circ}$ - Taça reconstituída numa pequena área junto ao lábio.}

Forma: Pequena taça carenada sem asas. Bordo com lábio boleado limitado por uma larga ranhura. A parte superior da pança alarga-se acentuadamente no sentido lábio-carena, o que provoca que a parede superior apresente um grau elevado de obliquidade em relação à base. Esta tem um pé pequeno, quase plano, que no entanto, se toma côncavo no centro. MAYET XLIII.

Dimensões: Diâmetros: boca $-78 \mathrm{~mm}$, base $-30 \mathrm{~mm}$. Alturas: total - $62 \mathrm{~mm}$, carena - $28 \mathrm{~mm}$. Espessura: média $-3 \mathrm{~mm}$.

Pasta: Esbranquiçada (10YR 8/2-3) com muitos elementos não plásticos de pequenas dimensões (calcites, micas, ferruginosos e cerâmica moída), de fractura irregular. É difícil indicar o grau de porosidade e de dureza visto a parede extema ter sido coberta com fixador a fim de que a peça não se desfizesse. Este facto talvez indicie que a pasta não só é muito porosa como muito branda.

Cobertura: Extema - Engobe em mau estado devido às condições de deposição e do restauro efectuado. Apresenta, no entanto, áreas matisadas em que são preponderantes as tonalidades laranjas (5YR 6/8); Interna - Engobe 
que parece ter sido de boa qualidade e espesso, matizado, de tonalidade laranja escuro (5 YR 6/8) e castanho muito escuro ou preto (impossível apresentar código de Munsell devido à peça estar completa).

Decoração: A parede externa na parte superior da pança é decorada a barbotina com motivos mamilares, em duas filas horizontais paralelas, de dimensões médias, de técnica pouco apurada e distribuídos aleatoriamente.

Proveniência: Horta das Pinas (S. Vicente e Ventosa, Eivas).

Cronologia: Segunda metade do séc. I d. C.

Peça referida em: Viana, A. e Deus, A. M. de (1950) - Op. cit., fig. 21, n. ${ }^{\circ} 73$ e n. ${ }^{\circ}$ fig. 22 82(.2); Idem (1956) - Op. cit., est. VI(.3), n. ${ }^{\circ} 36$.

N. ${ }^{\circ}$ de Inventário: $\mathrm{MNE}-2894$.

\section{$\mathrm{N}^{\circ} 7$ - Taça fragmentada, dispondo-se apenas de cerca de metade.}

Forma: Taça hemisférica sem asas com bordo ligeiramente esvasado e lábio boleado, demarcado da pança por uma ranhura muito fina. Aparte inferior da pança termina em "escada invertida" com dois degraus obtidos pela introdução de ranhuras. Base quase plana com pé pouco diferenciado. MAYET XXXVII.

Dimensões: Diâmetros: boca $-82 \mathrm{~mm}$, base $-35 \mathrm{~mm}$. Alturas: total - $69 \mathrm{~mm}$. Espessura: média - $2 \mathrm{~mm}$.

Pasta: Ocre esbranquiçado (10YR 8/3), pouco homogénea, branda, muito porosa, de fractura não rectilínea.

Cobertura: Externa - devido às condições de deposição e limpeza efectuada na parede externa (ácido(?), canivete) não se consegue detectar qualquer tipo de engobe, no entanto, na ranhura que separa os dois círculos concêntricos que decoram a base, detectaram-se umas pequenas manchas de engobe de tonalidade laranja (5YR 5/8); Interna - Completamente destituída de qualquer testemunho que pudesse indicar a existência de engobe, desaparecido devido ao processo de limpeza efectuado.

Decoração: Apresenta uma depressão (total possível de quatro), realizada muito provavelmente com o polegar, embora a perfeição do círculo obtido possa supor que esta tenha sido efectuada pelo oleiro com o recurso a qualquer instrumento de forma circular.

Proveniência: Horta das Pinas (S. Vicente e Ventosa, Eivas).

Cronologia: Reinados de Cláudio e Flávios.

Peça referida em: Viana, A. e Deus, A. M. de (1950) - Op. cit., fig. 21, n. ${ }^{\circ} 75$; Idem (1956) - Op. cit., est. V(.5), n. ${ }^{\circ} 59$.

N. ${ }^{\circ}$ de Inventário: MNE - 2942. 


\section{BIBLIOGRAFIA}

ALARCÃO, Jorge de (1983) - Portugal Romano. 3a ed., Lisboa: Editorial Verbo.

AlARCÃo, Jorge de (1988) - Roman Portugal. Warminster: Aris \& Phillips, vol. 2 - Gazetteer, p. 153-158.

AlARCÃO, Jorge de (1988) - O Domínio Romano em Portugal. Mem Martins: Publicações Europa-América, Col. Forum da História n. ${ }^{\circ} 1$.

AlARCÃO, Jorge de (1990) —A produção e circulação de produtos. In: SERRÃo, Joel e MARQUeS, A. H. de Oliveira (Dir.) — Nova História de Portugal. Lisboa: Editorial Presença, voi. 1, p.409-441.

BÉMONT, Colette (1976) - Vases à parois fines de Glanum: formes et décors. Gallia. Paris: Centre National de la Recherche Scientifique. 34 (1), p. 237-277.

Brown, A. E. e WoOdFIELD, Charmian (1983) - Excavations at Towcester, Northamptonshire: The Alchester Road Suburb. Northamptonshire Archaeology. Northamptonshire: s. ed., 18, p. 43-140.

CARVAlHO, Antonio (1992) - A villa romana da Quinta das Longas (S. Vicente e Ventosa, Eivas). Al-madan. Almada: Centro de Arqueologia de Almada, II ${ }^{a}$ Série, n. ${ }^{\circ} 1$ (Dez.), p. 90.

Carvalho, Antonio (1993) - A Villa Romana da Quinta das Longas (S. Vicente e Ventosa), Eivas. Eivas: Câmara Municipal de Eivas. (Desdobrável).

CARValHo, António (1994) - A villa romana da Quinta das Longas (S. Vicente e Ventosa, Eivas): As prospecções de 1990. In Actas das V Jornadas Arqueológicas da Associação dos Arqueólogos Portugueses. Lisboa: Associação dos Arqueólogos Portugueses, voi. 2, pp. 239-251.

Carvalho, António (1995) - As villae do Portugal romano. Revista de Arqueologia. Madrid: s. ed. (No prelo).

CARVAlHo, António e SEPÚlVEDA, Eurico - A villa romana da Quinta das Longas ( $S$.

Vicente e Ventosa, Eivas): As cerâmicas romanas de paredes finas, (em preparação).

Centeno, Rui (1983) — A dominação romana. In SARAiva, José Hermano (Dir.) - História de Portugal. Lisboa: Publicações Alfa, voi. 1, p. 149-212.

Dannell, G. B.; Hartley, B. R.; Wild, J. P. e Perrin, J. R. (1993) - Excavations on a Roman-British pottery production site at Park Farm, Stanground, Peterborough, 1965-1967. Journal of Roman Pottery Studies. Oxford: Oxbow Books, voi. 6, p. 51-93.

Deus, Antonio Dias de; Louro, Henrique da Silva e VianA, Abel (1955) — Apontamento de estações romanas e visigóticas da região de Eivas (Portugal). In: III Congreso Arqueológico Nacional — Galicia, 1953. Zaragoza: Institución Femando el Católico (Sección de Arqueología) - Secretaría General de los Congresos Nacionales, p. 568-578.

FABIÃO, Carlos (1992) - A romanização do actual território português. In MATTOSO, José (Dir.) - Historia de Portugal. Lisboa: Círculo de Leitores, vol. 1, p. 203-293.

GreENE, Kevin (1979) - The Pre-Flavian fine ware. Report on the excavations at Usk, 1965-1976. Cardiff: University of Wales Press. 
LAMBOglia, Nino (1949) - La estratigrafía de Albintimilium y la cronologia de la cerámica romana. Ampurias. Barcelona: Diputación Provincial de Barcelona — Instituto Diego Velázquez. 11, p. 47-61.

LAMBOGlia, Nino (1950) - Gli scavi di Albintimilium e la cronologia della ceramica romana. Parte Prima. Campagne di Scavo 1938-1940. Bordighera: Istituto Intemazional di Studi Liguri.

LOPES, Maria da Conceição (1994) - A Sigillata de Represas — Tratamento Informático. Coimbra: Universidade de Coimbra-Faculdade de Letras-Instituto de Arqueologia, Coi. Conimbriga/Anexos n. ${ }^{\circ} 2$. $^{2}$

LOPEZ MULLOR, Alberto (1990) — Las cerámicas romanas de paredes finas en Cataluña. Zaragoza: Libros Pórtico, 2 vols.

MAIOLI, Maria Grazia (1972-73) - Vasi a pareti sottili grigie dal Ravennate. Rei Cretariae Romanae Fautorum Acta. Ravena: s. ed., 14-15, p. 106-124.

MAIURI, A. (1933) - La Casa del Menandro e il suo tesoro di argentaría. Roma: s. ed..

MAYET, Françoise (1975) - Les céramiques a parois fines dans la Péninsule Ibérique. Paris: Diffusion E. de Boccard.

MAYET, Françoise (1976) - Céramiques à parois fines. In: ALARCÃO, Jorge de e ÉTIENNE, Robert (Dir.) - Fouilles de Conimbriga. VI - Céramiques Diverses et Verres. Paris: Diffusion E. de Boccard, vol. 6, p. 27-37.

MAYET, Françoise (1980) - Les céramiques à parois fines: état de la question. In: Céramiques Hellénistiques et Romaines. Paris: Centre de Recherches d'Histoire Ancienne, vol. 36, p. 201-221.

MingueZ MoRALeS, José Antonio (1991) - La cerámica romana de paredes finas: generalidades. Universidade de Zaragoza: Departamiento de Ciências de la Antiguidad.

MoEvs, Maria Teresa Marabini (1973) - The Roman thin walled pottery from Cosa (1948-54). Roma: American Academy in Rome. Col. Memories of the American Academy in Rome, voi. 32.

NoLEN, Jeannette U. Smit (1981) —A grave group from Monte dos Irmãos (Montargli). Conimbriga. Coimbra: Universidade de Coimbra-Faculdade de Letras

- Instituto de Arqueologia, 20, p. 181-192.

Nolen, Jeannette U. Smit (1994) - Cerâmicas e Vidros de Torre de Ares - Balsa. Lisboa: Instituto Português de Museus-Museu Nacional de Arqueologia.

PAÇO, Afonso do e FERreirA, Octávio da Veiga (1951) - Antiguidades de Fontalva (Eivas). Revista de Guimarães. Guimarães: Sociedade Martins Sarmento, 61 (3-4), Jul.-Dez.,p. 416-425.

PaÇO, Afonso do; Ferreira, Octávio da Veiga e VianA, Abel (1957) —Antiguidades de Fontalva. Neo-eneolitico e época romana. Zephyrus. Salamanca: Universidade de Salamanca, 8 (1), p. 111-133.

RIBEIRO, Femando Nunes (1956) - Breve informação sobre cerâmica romana das Represas. Beja: Ed. do autor.

RICCI, Andreina (1985) - Ceramica a pareti sottili. In: Atlante delle forme. Ceramiche. II-Ceramica fine romana nel bacino Mediterraneo (Tardo Ellenismo e Primo 
Imperio). Roma: Istituto della Enciclopedia Italiana, p. 211-253..

SEPÚlVEDA, Eurico - Cerâmica romana de paredes finas de Troia (Setúbal-Portugal). (em preparação).

VEgAS, Mercedes (1973) - La cerámica común romana del Mediterráneo Ocidental. Barcelona: Universidad de Barcelona-Instituto de Arqueologia y Prehistoria, Col. Publicaciones Eventuales n. ${ }^{\circ} 22$.

VIANA, Abel (1950) - Contribuição para a arqueologia dos arredores de Eivas. Trabalhos de Antropologia e Etnologia. Porto:

— Faculdade de Ciências, 12(3-4), p. 289-322.

VIANA, Abel (1955) - Notas de Corografia Alentej ana. Brotéria: Revista Contemporánea de Cultura. Lisboa: Gaspar Maria Leal Gomes Pereira Cabral. 61 (6), p. $545-556$.

VIANA, Abel (1956) - Algumas notas sobre António Dias de Deus e as suas pesquisas arqueológicas no concelho de Eivas. Beja: Ed. de autor.

VIANA, Abel e DEUS, António Dias de (1950) - Necrópolis céltico-romanas del concejo de Eivas (Portugal). Archivo Español de Arqueologia. Madrid: Consejo Superior de Investigaciones Cientificas-Instituto Diego Velazquez. 23 (80), p. 229-254.

VianA, Abel e DEUS, Antonio Dias de (1953) — Exploração de algumas necrópoles céltico-romanas do concelho de Elvas. In: XIII Congresso Luso-Espanhol para o Progresso das Ciências - Lisboa - 1950 - 7a Secção - Ciências Históricas e Filosóficas. Lisboa: Associação Portuguesa para o Progresso das Ciências, 8, p. 61-1 A.

ViAnA, Abel e DeUS, António Dias de (1955a) - Nuevas necropolis celto-romanas de la region de Eivas (Portugal). Archivo Español de Arqueologia. Madrid: Consejo Superior de Investigaciones Cientificas-Instituto Español de Arqueologia y Prehistoria "Rodrigo Caro". 28(91) p. 33-68.

Viana, Abel e Deus, António Dias de (1955b) - Necropolis de la Torre das Arcas. Archivo Español de Arqueologia. Madrid: Consejo Superior de Investigaciones Cientificas-Instituto Español de Arqueologia y Prehistoria "Rodrigo Caro". 28(92) p. 244-263.

Viana, Abel e Deus, António Dias de (1956) - Campos de umas do concelho de Eivas. O Instituto: Revista Científica e Literária. Lisboa: Instituto de Coimbra, 118, p. 133-193.

VIEGAS, João Rosa; NolEn, Jeannette U. Smit e DIAS, Maria Luisa Ferrer (1981) - A Necrópole de Santo André. Conimbriga. Coimbra: Universidade de CoimbraFaculdade de Letras-Instituto de Arqueologia, 20, p. 5-180. 


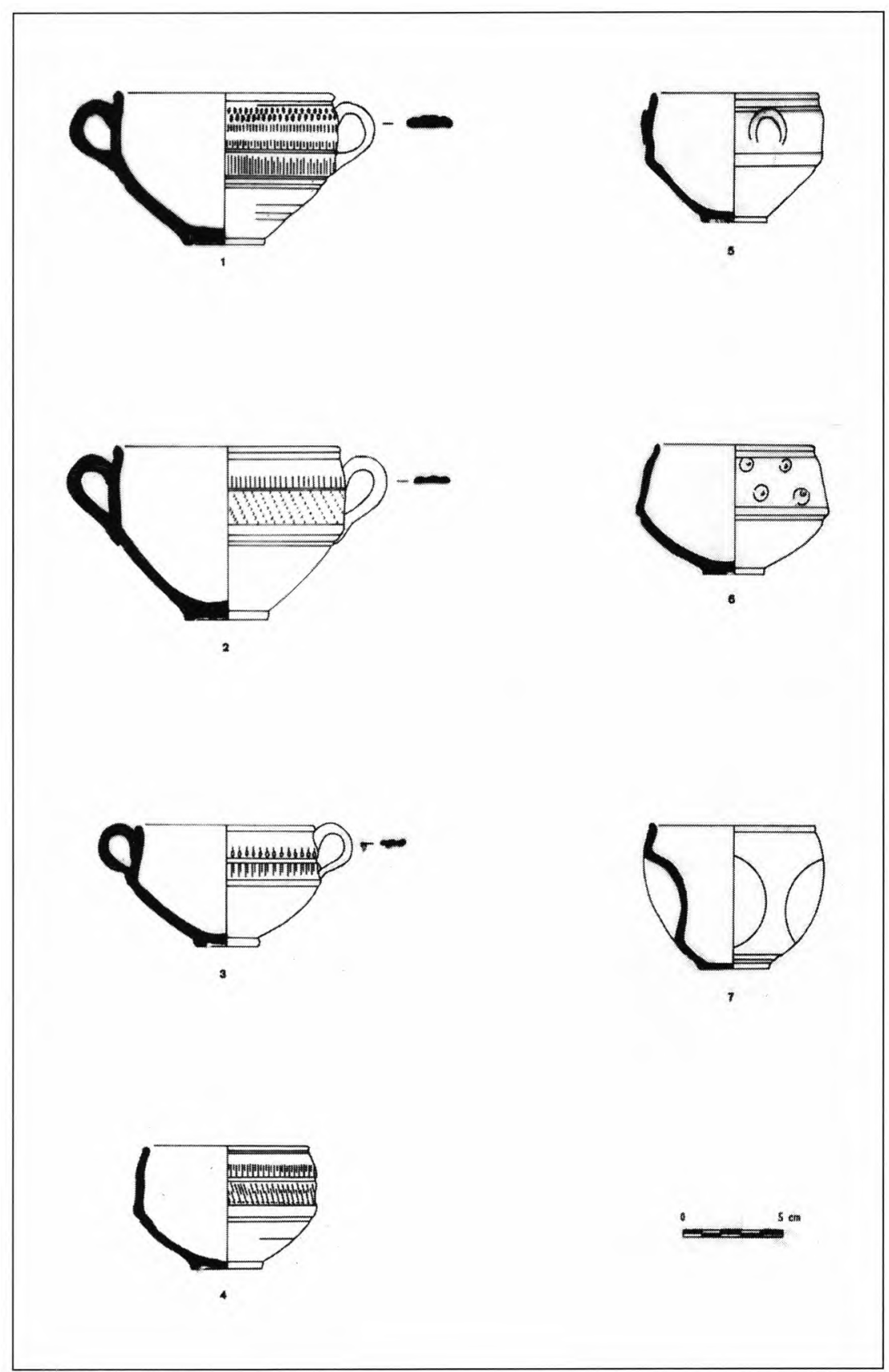

